Kevles DJ. Ananda Chakrabarty wins a patent: biotechnology, law, and society. Hist Stud Phys Biol Sci. 1994;25(Pt 1):111-35.

Reproduced with permission of the author.

Pages 114 and 116 have been cropped to remove copyrighted images. Page 134 has been deleted to remove copyrighted images. 
Ananda Chakrabarty wins a patent:

Biotechnology, law, and society, 1972-1980

THE UNITED STATES Supreme Court often grants eponymous fame to persons in dispute before it by linking their names to decisions of profound legal or constitutional significance. Among the people who have been thus lifted into history is Ananda M. Chakrabarty, a biochemist who came to the attention of the Court in the late 1970s because he had applied for a patent on a live animal-a bacterium that he had biologically engineered to eat crude oil. By its bicentennial, the United States had issued almost four million patents, some seventy of which covered mixtures or compounds that included microrganisms in unmodified form. However, only one (patent number 141,072, granted to Louis Pasteur, in 1873, for a purified yeast) had ever been awarded solely for a vital creature. ${ }^{I}$

What blocked Chakrabarty's claim was a longstanding tenet of common patent law that dated back at least to 1889 , when, in a landmark ruling, the U.S. Commissioner of Patents rejected an application for a patent to cover a fiber identified in the needles of a pine tree, noting that ascertaining the composition of the trees in the forest was "not a patentable invention, recognized by statute, any more than to find a new gem or jewel in the earth would entitle the discoverer to patent all gems which should be subsequently found." The commissioner added that it would be "unreasonable and impossible" to allow patents upon the trees of the forest and the plants of the earth. ${ }^{2}$ The commissioner's ruling formed the basis for what came to

*Califorrita Institute of Technology, Humanities and Social Sciences 228-77, Pasadena, California 91125 . For assistance in the prepartion of this article, I am grateful to the Andrew $W$. Mellon Foundation, the people who granted me time for interviews and are cited in the notes, and Diana Wear.

1. Diamond v. Chakrabarty, 447 U.S. 303, 100 S.Ct. (1980), 2207; Historical statistics of the United States, Colonial times to 1970 (2 vols., Washington, D.C., 1975), 2, 957-59; In the Supreme Court of the United States, Docket No. 79-136, Diamond v. Chakrabarty, Brief for the respondent [Jan 1980], 18-19, 50-51; Brief for the petitioner []an 1980], 2-3; Frank P. Darr, "Expanding patent coverage; Policy implications of Diamond y. Chakrabarty," Ohio State law journal, 42 (1981), 1071.

2. Ex Parte Latimer, 12 Mar 1889, C.D., 46 O.G. 1638, U.S, Patent Office, Decisions of the 
be known as the "product-of-nature" doctrine-that while processes devised to extract what is found in nature can be patented, objects discovered there can not. They are not inventions, nor can they as a class be made anyone's exclusive property. A living organism is not necessarily a strictly natural product. Plants and animals have been bred by human beings for millenia. Nevertheless, even those so devised were considered at base products of nature and unpatentable as such.

Moreover, patent law insisted that an invention be disclosed specifically enough to be uniquely defined and identically reproduced. It was difficult to specify the composition of a living organism, in the state of biochemical and genetic knowledge in the first half of this century. It was also difficult to specify methods by which identical reproduction of an organism could be achieved. Sexually reproducing organisms, left to themselves, do not generally breed identically true to type from one generation to the next. Thus, patents on sexually reproduced plants or animals could not be straightforwardly enforced because the progeny would be different from the patented parent.

However, the development of patent law for living organisms has turned on more than purely technical legal considerations. ${ }^{3}$ Like other areas of law, the patenting of life has also been shaped by the play of economic interests operating in tandem with changes in science and technology. From the turn of the century, plant breeders increasingly argued for patent protection of their products. The horticultural wing of the group succeeded in 1930 , when Congress passed the Plant Patent Act, which accommodated the basic tenets of patent law to the fundamental problem of biological specificity. The act limited protection to plants that could be reproduced asexually. Often termed cloning, asexual reproduction is accomplished by budding, grafting, rooting clippings, or dividing bulbs; it yields progeny genetically identical to the parent plant or tree. In 1970 , the breeders of sexually reproduced plants achieved a kind of intellectual-property protection for their products with the passage of the Plant Variety Protection Act. The Act established a system of breeder's rights in the form of Plant Variety Protection Certificates (PVPCs) to be issued for seventeen years to new varieties that are distinct, stable, and uniform. ${ }^{4}$

Commissioner of Patents and of the United States Courts in Patent Cases...1889 (Washington, D.C., 1890). 123 27. See also H. Thome, "Relation of patent law to natural products," Patent Office Sociesy, Journal, 6 (1923), 23-28.

3. Most accounis of the subject have tefided to treat its evolution as purely an affair of legal logic. An exception to the rule is the indispersable Stephen A. Bent et al., Intellectual property rights in biotechnology worldwide (New York, 1987). Also helpful is F.K. Beier, R.S. Crespi, and J. Straus, Blotechnology and patent protection: An international review (Paris, 1985).

4. Glemn Bugos and Daniet J. Kevles, "Plants as intellectual property: American law, policy, and practice in world context," Osiris, 7 (1992), 119-48. 
The Chakrabarty case also felt the impact of political and scientific economy on patent law. Although for several years the case evolved without fanfare, by the time it reached the Supreme Court, it had become charged with the social and economic stakes surrounding the swiftly accelerating commercialization of molecular biology, a high-stakes field naturally concerned with the scope of intellectual property rights in living organisms. $^{s}$

\section{THE INITIAL CASE (CHAKRABARTY)}

Chakrabarty, the Brahman son of a grain merchant in his native India, eamed a Ph.D. at the University of Calcutta and came to the United States, in 1965, as a postdoctoral fellow at the University of Illinois. His wife, Krishna, who was also a biochemist, had met him in Calcutta and then taken an academic position in California. She later recalled to a reporter that, while she was there, "someone came from India and told me I was engaged," adding, "My father knew he had to find a man modern enough to suit my needs but old-fashioned enough to suit his." At Illinois, where Krishna also had a post, Chakrabarty was to investigate a very modern subject-the transformation of organic compounds by bacteria, particularly strains of the common genus Pseudomonas. These microorganisms are rodshaped and a few ten thousandths of an inch long; some varieties give off pigments that color water shades of green or blue; many make excellent natural scavengers, able to feed on a number of exotic chemical compounds. ${ }^{6}$ Chakrabarty developed a special interest in the ability of the bugs to degrade one or another hydrocarbon-a chain of carbon and hydrogen atoms that, in different forms, comprises the backbone of several common organic substances, including petroleum--and digest it into protein.

5. Several works in recent years have pioneered the treatment of intellectual property in terms of political economy. The key work for plants is Jack R. Xloppenburg, Jr., First the seed: The political economy of plant biotechnology, 1492-2000 (New York, 1988), which can be supplemented by Calestous Juma, The gene hunters: Biotechnology and the scramble for seeds (Princeton, 1989). The literature that touches on intellectual property in biotechnology is vast. Excellent entry into it can be obtained from Charles Weiner, "Professors and patents: A continuing controversy," Technology review, 89 (Feb/Mar 1986), 33-43 and "Patenting and acadenic research: Historical case studies, "Science, technology, and human values, 12 (1987), 50-56; William H. Lesser, ed., Animal patents: The legal, economic, and social issues (New York, 1989); Sheldon Krimsky, Biotechnics and society; The rise of industrial genetics (New York, 1991).

6. People, 14 (14 Jul 1980), 38; Graham S. Wilson and A. Ashley Miles, Topley and Wilson's principles of bacteriology and immunity (5th ed., 2 vols., London, 1964), 1, 636-38; author's telephone interview with Ananda M. Chakrabarty, 8 Aug 1988. 
F1G. 1 Ananda Chakrabarty. Source: "The right to patent life," Newsweek, 95 (30 June 1985), 74.

In 1971, Chakrabarty joined the staff of the General Electric Research Center in Schenectady, New York. Bacterial processes were far from the company's traditional concerns, which lay in physical technologies ranging from toasters to jet engines. However, in the early 1970s, federal investment in aerospace was contracting and the supersonic transport project, in which GE had a part, was on its way to cancellation. The company, deemphasizing its space-work, was redirecting part of its research and development program into the burgeoning fields of environmental science and pollution control. Chakrabarty was hired to help a group at the Schenectady Center engaged in turning cow manure, which was produced in collectible abundance at feed lots in the southwestern United States, into a protein-rich source of animal food. His job was to figure out how to use bacteria to degrade certain compounds in the manure that animals found difficult to digest. But the work did not involve hydrocarbon degradation- "my first love," Chakrabarty recalled in a conversation-so he came into the laboratory to work on that subject after hours and on weekends. ${ }^{7}$

7. "Declaration of Chaikrabarty" in U.S. Court of Customs and Patent Appeals, Transcript af record, Patent Appeal Docket No. 77-535. In the matter of the application of Ananda $M$. Chatrabarty, applicant (Heteafter, Transcript of record.. Chakrabarty), 75-76; "Interview" (nel, 6). 
At Illinois, Chakrabarty's explorations of hydrocarbons had been aimed at the acquisition of basic knowledge; at General Electric, he pointed towards practical problem-solving, starting with the production of protein from oil. The idea, he explained, was to grow Pseudomonas in oil; "you harvest the bugs and you have a source of protein." Since at the time oil was cheap and protein expensive in many regions of the world, exploiting microorganisms to turn hydrocarbons into food stuffs 'made sufficient economic sense to have attracted substantial investment from petrochemical firms in Britain and France. ${ }^{8}$ It also made environmental sense to deploy them to deal with the newly manifest problem of major oil spills. In 1967, the tanker Torrey Canyon had run aground off the southwest coast of Britain, leaking some 100,000 tons of crude oil onto the beaches of Britain and France, and, in 1969, a Union Oil Company well off the coast of Santa Barbara, California, had spilled 235,000 gallons of crude over almost 8,000 square miles of sea. The two disasters showed that vast oil spills were vastly expensive to clean up and that the world had no truly effective technology to accomplish the task." Chakrabarty remembered, "Because I was getting interested in practical aspects of what you call biotechnology today, I was thinking a little bit about whether I could actually make a bug that would grow rapidly with oil" -a single bacterium capable by itself of digesting not just one or another of the hydrocarbons in petroleum but a whole spectrum of them. By early 1972, his off-hours efforts had yielded the oileating bug. ${ }^{10}$

The discovery was suggested by what he had learned at Illinois. Pseudomonas accomplish their prodigious feats of scavenging with genes that produce enzymes; the enzymes permit them to degrade compounds like hydrocarbons. Chakrabarty recounted, "It occurred to us that maybe one of the reasons why the Pseudomonas can do this so voraciously is because they harbor the necessary genes not on their chromosome but on plasmids"-that is, loops of deoxyribonucleic acid (DNA) located in the cell apart from the chromosome-m"so that they could transfer them from one bug to another." He added, "We actually demonstrated that the genes for degradation of the hydrocarbons in many Pseudomonas were borne on plasmids rather than on chromosomes." "11 To construct his oil-eating bug,

8. “Application of Ananda M. Chakrabarty, Filed June 7, 1972, serial number 260,563, for microorganisms having multiple, compatible degradative energy-generating plasmids and preparation thereof;" "Declaration" (ref. 7) 6-7, 75-76; Daniel I.C. Wang, "Proteins from petroleum," Chemical engineering, 75 (26 Aug 1968), 99-108.

9. Business week (8 Feb 1969), 60; Time (7 Apr 1967), 28; Science news, 95 (22 Feb 1969), $183-184$.

10. "Ynterview" (ref. 6).

11. Ibid. 
Chakrabarty transferred the plasmids by design, successively mating one strain of bacteria with another, then fusing certain of the plasmids together with $X$ rays to ensure that they would coexist stably in the cell. Chakrabarty later summarized the trick for People magazine: "I simply shuffled genes, changing bacteria that already existed." 12 The shuffling yielded two new types of bacteria derived, respectively, from two strains of Pseudomonas, each containing a slightly different set of four genes for the digestion of at least as many of the hydrocarbons in oil. Each would consume large fractions not only of crude oil but also of Bunker C-the thick, sticky residuum left after the removal from the crude of its commercially valuable part--turning their hydrocarbons into bacterial cell meat that was seventy to eighty percent protein. ${ }^{13}$ 
FIG. 2 The oil-eating bugs. Source: "The right to patent life," Newsweek, 95 (30 June 1985), 74.

Early in 1972 , Chakrabarty arranged to give a talk on his work with Pseudomonas at a scientific conference in Tel Aviv. He recalled that "in $\mathrm{GE}$, if you are going to give an international talk, you have to have it approved by management... So I submitted a copy of my talk and it reached the desk of Arthur Bueche, who was the vice president of General Electric...He was a workaholic, always there, so I would see him in the men's room once in a while... He kind of knew me even though I was really low in the ranks." Encountering Chakrabarty in the men's room one day, Bueche mentioned the Tel Aviv talk and asked whether the oil-eating

12. People (ref. 6), 38.

13. "Declaration" (ref. 7); "Application" (ref. 8), 13-15, 38, 41-42, 47-52, 75-76; "Interview" (ref, 6). 
bugs were a serious proposition. "I said, 'Sure, that's why I'm going to give a talk.' He said, 'Ah-hah, but if you think that it's real, you are not supposed to give a talk; you are supposed to write a disclosure letter for a patent first.' I didn't know all these things. I was really quite new.' 14

Chakrabarty thinks that companies like the major drug firms, long accustomed to the product-of-nature barrier to patents, would not have filed a patent application on his new bugs. They would have limited the application to the process of constructing them. However, General Electric, not being a biological company, operated in a different patent culture. The General Electric patent lawyer assigned to the case was Leo I. MaLossi, who had been with the firm since 1963, was used to filing patent applications on items like refrigerators, plastics, jet engines, and nuclear power plants, and thought that if you invented something new and useful, you deserved a patent covering whatever claims about it you could legally make. ${ }^{15}$ Chakrabarty recalls telling MaLossi often that living creatures could not be patented. MaLossi would say, Why not?'16 MaLossi remembers, "When I first proposed to introduce the claims to the organism per se, I had occasion to speak to various patent attorneys who had worked in that type of technology.... What intrigued me was that all of them said that such claims were unpatentable, but they all gave me different reasons why. Now that got me to thinking that there's something funny here. So I read all the case law $I$ could lay my hand on that had any pertinence to the subject and then I became convinced that $I$ was right. What had happened is that [the inadmissability of claims to live matter] had become a canon of patent law and nobody questioned it." 17

What was patentable according to U.S. statute dated back to the patent law of 1793, which declared, in language written by Thomas Jefferson, that patents could be obtained for "any new and useful art, machine, manufacture, or composition of matter, or any new or useful improvement thereof." Jefferson's phrasing remained-and remains-at the core of the U.S. patent code, except for the 18 th-century word "art," which was replaced in a Congressional overhaul of patent law in 1952 by the word "process." 18 To MaLossi, aware that by now scientists understood living matter, including bacteria, to be chemicals, Chakrabarty's bugs were manufactures, new compositions of matter-and, hence, patentable. On June 7, 1972, Chakrabarty filed for a patent to cover not only the process by which he had constructed

14. "Interview" (ref, 6).

15. Ibid.; author's telephone interview with Leo I. MaLossi, 18 Arg 1988.

16. "Interview" (ref, 6); "Interview" (ref. 15).

17. Author's telephone interview with MaLossi, 23 Aug 1988.

18. Diamond v. Chakrabarty (ref. 1). 
his oil-eating bacteria but also the product-the living, genetically modified bacteria. $^{19}$

In September 1973, Alvin E. Tanenholtz, the patent examiner supervising the review of Chakrabarty's application, rejected the product claims for the bacteria per se, though not for the process of producing them; in April 1974, after several legal counters from MaLossi, he rejected the product claims finally. ${ }^{20}$ Throughout the legal jockeying, Tanenholtz' principal ground for rejection was that the bugs were products of nature; their four plasmids had made them different in degree from naturally occurring Psell domonas but not in kind. He also implied that living creatures were not patentable, if only because neither legislative nor case law had made them so. In a protest brief filed in June 1974 to the Patent Office's internal Board of Appeals, Leo MaLossi insisted that the bugs were not products of nature because Chakrabarty's manipulations of their plasmids had altered them fundamentally. He also argued that nothing in case law disallowed a patent because the product was alive and he contended that the bugs were patentable because Chakrabarty's alterations had tumed them into new compositions of matter. ${ }^{21}$

The three-man Board, ruling almost two years later on May 20, 1976, conceded that Chakrabarty's bacteria did not occur naturally and, hence, were not products of nature, but it upheld Tanenholtz' rejection of the claims on a new explicit ground: that the bacteria could not be patented because they were alive. The Board's reasoning apparently incorporated the proposition that what the law did not prohibit, it did not necessarily allow. Although statutory patent code did not proscribe patents on plants, Congress had felt the need to enact a special Plant Patent Act to reward plant breeders. The Board also was gripped by a specter that Tanenhoitz had raised in a reply to Malossi's brief: To adopt a broad interpretation of phrases such as "new composition of matter" would "open the flood gates to patentability for all newly produced microorganisms as well as for all newly developed multi-cellular animals such as...chickens and cattle." The

19. "Application" (ref. 7), 6-7.

20. Ray Penland was the patent examiner working on the case, but, according to Tanenholtz, Pealand did not then have signatory authority and he, Tanenholtz, was responsible for the arguments advanced against the grant of a patent for the bacteria up through the decision of the Bown of Appeals. Author's telephone interview with Alvin E. Tanenholtz, 29 Aug 1988.

21. "Letter of examiner," 19 Sep 1973; Chakrabarty,"Amendment," 6 Dec 1973; "Letter of examiner," 11 Jan 1974; Chakrabarty, "Amendment," 5 Apr 1974; Malossi, "Brief," 24 Jane 1974; "Examiner's answer," 23 Sep 1974; Malossi, "Reply brief," 10 Oct 1974; "Opinjon and decision of Board of Appeals," 20 May 1976, all in Transcript of record.. Chatrabarty (ref. 7), 59-61, 65-66, 68-73, 78-80, 82-84, 86-97. 
Board's ruling reiterated Tanenholtz' warning and added that if patents could be granted to single-cell organisms with additional plasmids, so might they be given for "multicellular organisms (including human beings)" with transplanted livers or hearts. Chakrabarty's bugs might not occur naturally, but the Board chose to emphasize "that a human being with a transplanted liver or heart is also not naturally occurring." 22

\section{ON APPEAL, IN CONTEXT}

The price of oil had by now quadrupled, making it more expensive than protein; the economic case for Chakrabarty's bugs was no longer compelling. However, the Board's ruling had changed the complexion of the case for MaLossi and his boss, Charles Watts, the General Electric Patent Counsel for Materials Science and Engineering. For MaLossi, prior to the Board's ruling Chakrabarty's had just been another workaday patent application. Now that the Board had shifted the issue to the patentability of living matter, MaLossi recognized with Watts that the G.E. patent department had been presented with an opportunity to participate in the making of new case law-an opportunity, Watts later refiected, that "you don't often get in a career as a lawyer, especially in a large corporation." ${ }^{23}$ General Electric decided to take Chakrabarty's case to the United States Court of Custom and Patent Appeals in Washington, D.C.

By this point, late 1976, Chakrabarty's claim had become entwined with a complementary case advanced by Malcolm E. Bergy and fellow scientists at the Upjohn Company. They had developed a process for obtaining a purified strain of the newly discovered fungus Streptomyces vellosus, whose metabolic chemistry generated the antibiotic lyncomycin. In June 1974, Upjohn had applied for a patent on the method, but an Upjohn patent lawyer named Roman Saliwanchik thought the claim incomplete. Saliwanchik had been trained as an undergraduate in microbiology and biochemistry. From the time he had begun to study cases in law school, he had been puzzled why a living organism should not be patentable only because it was living. He saw an opportunity to test that doctrine with Bergy's fungus: since it did not exist in nature as a biologically pure culture, it seemed to qualify for a patent as a manufacture. In January 1975, Saliwanchik enlarged Bergy's claim to include the product-the purified strain of the organism itself. ${ }^{24}$

22. "Examiner's answer," 23 Sep 1974; "Opinion and decision of Board of Appeals," 20 May 1976, in ibid., 86-89, 92-97.

23. "Interview" (ref. 17); author's interview with Charles Watts, 18 Aug 1988.

24. "Application of Malcolm E. Bergy," $10 \mathrm{June} \mathrm{1974,} \mathrm{in} \mathrm{United} \mathrm{States} \mathrm{Court} \mathrm{of} \mathrm{Customs}$ and Patent Appeals, Transcript of record, patent appeal docket No. 76-712, in re application 
The product application was initially rejected by a patent examiner on the ground that the fungus was a work of nature. In a brief addressed to the Board of Patent Appeals, on March 18, 1975, Saliwanchik insisted that the fungus was "not a product of nature" but "the product of a microbiologist." The Board sidestepped that issue to reject the claim, on June 22, 1976 , for the deeper reason that the fungus was alive-employing much the same arguments that it had used to deny Chakrabarty's product claim the previous month and warning, similarly, that a liberal interpretation of the code would lead to the patenting of "new types of insects, such as honeybees, or new varieties of animals produced by selective breeding and crossbreeding." The Upjohn lawyers promptly brought their case to the Court of Customs and Patent Appeals-promptly enough, as it happened, to arrive ahead of Chakrabarty's, which had been delayed in a further skirmish with the Patent Office Board. However, having been framed in almost the same terms, the Bergy case became a proxy for the issue that Chakrabarty's had initially raised. ${ }^{25}$ Indeed, in arguments before the Court, on March 3, 1977, the battle line was drawn precisely on the question whether living organisms qualified for patent protection under the Jeffersonian core of the patent code. ${ }^{26}$

On October 6, 1977, the Court ruled three to two in favor of Bergy. The majority opinion was delivered by Judge Giles $\mathrm{S}$. Rich, who, before his appointment to the federal bench, in 1956, had distinguished himself as a patent attorney during some thirty years of practice in New York City, and who manifestly recognized that life is chemistry. Rich viewed it as "illogical" to allow patents for processes that relied upon the functions of living organisms but to deny patents to a living manufacture or new composition of matter as such. He contended that in their nature and commercial uses biologically pure cultures of microorganisms were "much more akin to inanimate chemical compositions such as reactants, reagents, and catalysts than they are to horses and honeybees or raspberries and roses." $\mathrm{He}$ found nothing in the language of the patent laws that excluded such tools from patent protection solely on ground of their being alive; it was being alive that made them useful. "In short, we think the fact that microorganisms, as

of Malcolm E. Bergy, et al., filed 16 Aug 1976, 6; telephone conversation with Roman Saliwanchik, 14 Oct 1988.

25. "Letter of examiner, 6 Feb 1975;" Saliwanchik, "Brief," 18 Mar 1975; "Opinion and decision of Board of Appeals, June 22, 1976" in Transcript of record., Bergy (ref. 24), 34, 54, 62-63; In the matter of the application of Malcolm E. Bergy et al. patent appeal no. 76712, U.S. Court of Customs and Patent Appeals, 563 F. 2d, 1032-1035 (1977); Application of Ananda M. Chakrabarty. Patent Appeal No. 77-535, U.S. Court of Custonts and Patent Appeals, 571 F. 2d, 42 (1978).

26. Application of Malcolm E. Bergy (ret. 25), 1034-1035. 
distinguished from chemical compounds, are alive is a distinction without legal significance." Rich took note of the fear that allowing patents for microorganisms would make patentable "all new, useful, and unobvious species of plants, animals, and insects created by man." He called the fear "far-fetched," while observing that, in any case, "that question is not before us.,"27

MaLossi argued Chakrabarty's case on December 5, 1977. On March 2, 1978 the Court ruled three-to-two in Chakrabarty's favor. Judge Rich, speaking for the majority, saw only one issue-the patentability of living organisms. The Court had dealt with the identical issue in the Bergy case and found its reasoning there sufficient and controlling. In a concurring opinion, Judge Howard T. Markey declared, "The [patent] statute is not ambiguous. No Congressional intent to limit patents to dead inventions lurks in the lacuna of the statute, and there is no grave or compelling circumstance requiring us to find it there." And he added, "As with Fulton's steamboat "folly' and Bell's telephone 'toy,' new technologies have historically encountered resistance. But, if our patent laws are to achieve their objective, extra-legal efforts to restrict wholly new technologies to the technological parameters of the past must be eschewed." 28

Ranking lawyers in the U.S. Patent Office now had to decide whether to appeal the decision to the Supreme Court, and it was at this point that considerations of the political economy of biotechnology began to figure in the case. The scientific key to the commercialization of molecular biology was the technique of recombinant DNA that had been co-invented, in 1973, by Herbert Boyer and Stanley Cohen, biologists at, respectively, the University of California San Francisco Medical School and Stanford University. The advent of the technology provoked controversy, as scientists warned that its use might lead to the release of dangerous new organisms into the environment or throw evolution off course. Apprehension spread rapidly through the lay community, stimulating moves in state legislatures and the United States Congress to impose severe restrictions on research with recombinant DNA. By 1978, most molecular biologists were convinced that the dangers had been exaggerated. The National Institutes of Health established regulations for the confinement of recombinant research to safe facilities. And the trend to acceptance of recombinant techniques was being reinforced by the growing commercial interest in them.

Herbert Boyer had helped lead the way. In 1976, Boyer and a venture capitalist named Robert A. Swanson formed the biotechnology firm Genentech-short for "genetic engineering technology." In 1977, the

27. Ibid., 1037-1038.

28. Application of Ananda M. Chakrabarty (ref. 25), 43-44. 


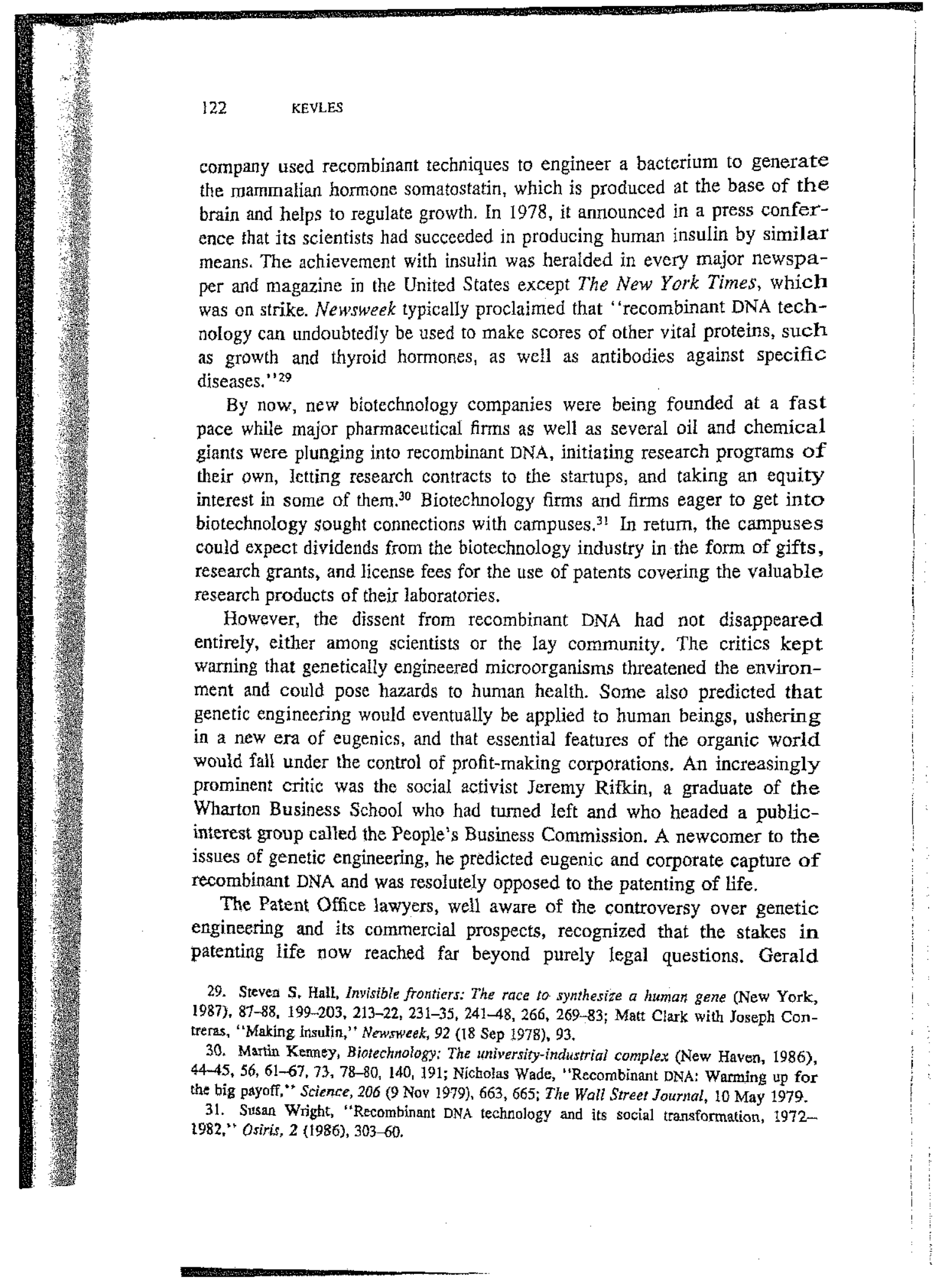


Bjorge, the Associate Solicitor in the Patent Office, remembered a key point in the discussions about whether to appeal the Bergy and Chakrabarty cases to the U.S. Supreme Court: belief that living products could be patented would call forth considerable investment in biotechnological enterprises. However, while the Court of Customs and Patent Appeals might today decide in favor of the patentability of living microorganisms, federal appeals courts elsewhere might in the future decide against it, placing the issue in legal limbo. An adverse ruling by the Supreme Court at that point would throw the biotechnology industry into turmoil. It would be better to have the high court clarify the issue sooner than later. If it ruled against Bergy and Chakrabarty, the issue could be referred to the Congress, where the Patent Office thought it belonged anyway. ${ }^{32}$

On April 20,1978, on behalf of the Patent Office, the Solicitor General of the United States moved to appeal the Bergy decision to the United States Supreme Court. He wamed in his petition that, "since the number of living things is vast, the decision opens an enormous range of subject matter to patentability," and that policymaking concerning the extension of the patent laws to new fields belonged to Congress, not the courts, and that allowing the Bergy ruling to stand would further complicate the "policy problems" - the brief noted the $1976 \mathrm{NIH}$ guidelines-"of genetic engineering, aiready highly controversial.," ${ }^{33}$ On June 26 , on the last day of its term, the Court ordered that the Bergy decision be vacated. It sent the case back to the patent appeals court for reconsideration in light of a decision that it had rendered four days earlier, in another patent case, Parker v. Flook." 34 In August, over MaLossi's objections, the appeals court vacated its judgment in Chakrabarty's case, too, also compelling reconsideration of it in light of Flook. Though the two cases were not formally consolidated, the appeals court chose to deal with them together, receiving briefs from the parties in September and October and hearing arguments on both on November 6,1978.35

The Supreme Court had given no specific indication of the relevance of Flook to Bergy's claim, which compounded the uncertainty since the case

32. Telephone interview with Gerald Bjorge, 12 Mar 1989.

33. Solicitor General, Petition for a writ of certiorari... In the Supreme Court of the United States, October Term 1977, Lutrelle F. Parker v. Malcolm E. Bergy et al., docket no. 77-1503, filed 20 Apr $1978,6-7$.

34. Parker v. Flook, 437 U.S. 584, 98 Ct. 2522, at 2528; "Application of Malcolm E. Bergy..., Application of Ananda M. Chakrabarty," Appeal Nos. 76-712, 77-535, U.S. Court of Customs and Patent Appeals, 29 Mar 1979, 596 Federal Reporter, 952, at 957.

35. "Supplemental brief for appellant," U.S. Court of Customs and Patent Appeals, patent appeal docket no. 77-535, "In re application of Ananda M. Chakrabarty, appellant" [iiled fall 1978], 4. 
concerned the patentability of a mathematical algorithm for the control of a production process. Under the circumstances, each of the principal parties in the proceeding found in Flook what suited its interest. The government's lawyers locked onto a point in one of the precedents that the high court had cited in the case-that an expansion of patent rights "would require a clear and certain signal from Congress"-and contended yet again that, since Congress had not provided for the patenting of living matter, neither Bergy's nor Chakrabarty's claim should be allowed. But while introducing the precedent, the Court had observed that "we must proceed cautiously when we are asked to extend patent rights into areas wholly unforeseen by Congress." "36

Leo MaLossi ingeniously turned that observation to Chakrabarty's advantage by pointing out, in his brief, that Chakrabarty's oil-eating bugs did not fall into an area of innovation that Congress had not foreseen. They had not been produced by recombinant DNA in the sense of contemporary genetic engineering but had been devised by a traditional method of recombining DNA-by the interbreeding of different strains, hybridization. Congress had been familiar with plant and animal breeding since the founding of the republic-George Washington himself had been instrumental in the promotion and improvement of mule breeding, MaLossi noted-and yet it had never prohibited the patenting of living organisms. On the contrary, Congressional committee reports drawn up in connection with the last major overhaul of U.S. patent law, in 1952, had declared that an invention could be "anything under the sun." MaLossi concluded that Flook had no bearing on Chakrabarty's claims. Saliwanchik concluded similarly about his client Bergy's claim, arguing that, since it concerned only the purification of a microrganism, it was irrelevant to disputes about mathematical algorithms or genetic engineering..$^{37}$

Both cases were taken to be weighted with sufficiently broad import for the future of biotechnology as to prompt Genentech and the University of California to file amicus briefs-the former's within two weeks of the insulin press conference-on the side of Bergy and Chakrabarty. Under the terms of Genentech's contracts for the somatostatin project, UC San

36. Parker v. Flook (ref. 34); "Supplemental brief for the Commissioner of Patents and Trademarks," filed 20 Oct 1978, U.S. Court of Customs and Patent Appeals, patent appeal no. 77-535, "In the matter of the application of Ananda M. Chakrabarty," 4.

37. "Supplemental brief for appellant" (ref. 35), 4, 6-8, 15, 22; Saliwanchik, "Brief in opposition to petition for writ of certiorari..." In the Supreme Court of the United States, OCtober Term 1977, No. 77-1503, Lutrelle F. Parker v. Malcolm E. Bergy, filed 11 May 1978, 5; "Supplemental brief for appellants," U.S. Court of Customs and Patent Appeals, patent appeal docket no. 76-712, "In re application of Malcolm E. Bergy, et al.," appellants, 2-4; telephone interview with Gerald Bjorge, 12 Mar 1989. 
Francisco and City of Hope could patent the results, giving Genentech an exclusive license to produce the hormone. Genentech itself would seek the patent on the recombinant insulin developed in its own laboratory. Now, the university and Genentech each declared that it had a vital stake in the outcame of the matter-the university, because it expected to realize income on patents for genetically engineered products invented in its laboratories; the company, because the patent incentive would be "an important if not indispensable factor in attracting private capital support for life-giving research in the pharmaceutical field." Neither proposed to argue the particular merits of the Bergy or Chakrabarty claims, preferring to address the key principle at stake-that is, the patentability of living organisms. The university stressed that at issue was only the patentability of "single-cell organisms which are mindless, soulless and brainless," not that of higher life forms. Along with Genentech but more expansively, it also contended that the line between dead chemicals and living microrganisms was "wellnigh imperceptible," adding that, in this respect, even skilled scientists could only with difficulty draw "a bright line between life and its absence" and that recognition of that fact "destroys the argument that life itself. . .precludes patentability." 38

Both amicus briefs conceded that recombinant genetic engineering was a new technology. In the view of the university, however, it was unimaginable that the Congress of 1793 had intended to disqualify from patent protection "the fruits of human creativity in then unknown technologies, whether airplanes, space craft, or, now, genetically engineered microorganisms." Genentech's counsel-he was Thomas D. Kiley, of the Los Angeles firm of Lyon \& Lyon-acknowledged that the courts might be doubly cautious in permitting patents in areas of innovation that, like genetic engineering, were both unanticipated by Congress and controversial. But he observed that it was "not the job of the Patent System to regulate new technologies, but rather to bring them into being, and into public view...Congress is quite capable of regulating the use of technology without judicial gerrymandering of the System that inspires its creation. A veritable alphabet soup of other Agencies attests to that." In Kiley's view, the govemment's concern with the controversialism of genetic engineering was " a red herring." "39

38. Kenney, Biotechnology, 94-96; The Wall Street Journal (7 Sep 1978), 17; Saliwanchik (ref. 25), Lutrelle F. Parker v. Malcolm E. Bergy (ref, 33); "Brief amicus curiae of the Regents of the University of California," U.S. Court of Customs and Patent Appeals, patent appeal dockets nos. 76-712 and 77-535, In the matter of.,Bergy and In the matter of...Chakrabarty, 1, 2, 14-20; "Motion for leave to appear as amicus curiae and brief amicus curiae of Genentech, Inc." ibid., United States Court of Custom and Patent Appeals, filed 20 Sep $1978,1 b-1 d, 6,8-9,12-13$.

39. "University of California" (ref. 38); "Genentech" (ref. 38). 
On March 29, 1979, the Court of Customs and Patent Appeals held by a three-to-two majority that it could find nothing in Flook that shed light on the Bergy and Chakrabarty cases. In a fifty-page opinion on behalf of the majority-the length of the opinion was unusual and was perhaps prompted by the likelihood that the cases would return to the Supreme Court-Judge Giles Rich noted that in oral argument the government's solicitor had admitted that the technologies at issue were not new, and Rich stressed that it was not necessary anyway for Congress to have foreseen a new field of technology to make inventions in it patentable. The majority rejected as "hyperbole" the solicitor's waming that if patents were allowed for microorganisms, they might have to be permitted for an enormous range of living matter. On the substantive merits, the majority position was unchanged from what it had been in the first round. Indeed, if anything, the position had been reinforced by Genentech's triumphs with somatostatin and insulin, which Rich's opinion endorsed by quoting from an enthusiastic report of them in Kiley's brief. Rich reiterated that "life is largely chemistry," declaring that the court could see "no legally significant difference between active chemicals which are classified as "dead" and organisms used for their chemical reactions which take place because they are "alive.", The court once again reversed the Patent Appeals Board, upholding Bergy's and Chakrabarty's claims-but this time by a majority of four to one, since another justice, although disagreeing with parts of Rich's opinion, concurred on the key issue of the patentability of living products. ${ }^{40}$

\section{IN THE SUPREME COURT}

Most high officials in the Patent Office agreed that the decision in the Bergy and Chakrabarty cases should once again be appealed to the Supreme Court, for much the same reasons as had moved them to do so the first time. According to the recollection of a staff member in the Patent Office, the principal exception in the Office was Donald Banner, the U.S. Commissioner of Patents, who had come to his post in 1978 from the Borg-Warner Corporation, where he had been general patent counsel, and who liked the decision of the appeals court. Determined to keep it away from the uncertainties of judgment by the Supreme Court, he wanted to let it stand. However, a discreet telephone call from the Patent Office brought Banner's obstructionist attitude to the attention of the Office of the U.S. Solicitor General, who, after determining Banner's views directly, promptly reminded the Patent Commissioner that the Solicitor General controlled the legal

40. "Application of Malcolm E. Bergy... Application of Ananda M. Chakrabarty" (ref. 34), on $952-53,955,967,973-75,984-5,986,999$. 
proceedings of federal agencies and that this Solicitor General-he was Wade McCree--intended to appeal the Bergy and Chakrabarty cases. On July 27, 1979, McCree petitioned the Supreme Court for review of the two cases and, on October 29 , review was granted. ${ }^{41}$

In December, the Upjohn lawyers amended their patent application to omit the product claim on Bergy's purified lyncomycin-a move that rendered the company's case moot and saved it the not inconsiderable cost of an appeal to the Supreme Court. Roman Saliwanchik later explained that the company thought its claim for the purified natural fungus was weak and might drag Chakrabarty's case, which was much stronger but which had become legally joined with Bergy's, down to defeat. However, Chakrabarty, though now unencumbered, did not have to fight on alone. By the end of January 1980, ten amicus briefs, most of them in support of his case, had been filed by various individuals and organizations, including, once again, Genentech and the University of California, but now also the Pharmaceutical Manufacturers Association, the American Patent Law Association, the New York Patent Law Association, and the American Society for Microbiology. The Supreme Court chambers were packed when, on March 17, 1980, the Justices heard oral arguments in the case, which was by then known as Diamond v. Chakrabarty-Sidney Diamond was the new Commissioner of Patents-and which had acquired a degree of economic and social interest far transcending the particulars of Ananda Chakrabarty's oil-eating bugs. ${ }^{42}$

The first amicus brief to be filed came from the People's Business Commission and was the only one to take the government's position. It attacked genetic engineering as such, warning that it might "irreversibly pollute the planetary gene pool in radical new ways" -yet several of its arguments were embraced and given credibility in the brief of the U.S. Solicitor General, which otherwise repeated the objections it had advanced against patenting life before the appeals court. ${ }^{43}$ As a result, the brief of the People's Business Commission-the PBC, as it referred to itself in the

41. Interview with a staff member in the Patent Office who does not wish to be identified.

42. In the Supreme Court of the United States, October Term, 1979, dacket no. 79-136, Motion to discuss and vacate as to respondents Malcolm E. Bergy, et al., 20 Dec 1979, Pp. 1a-2a; The Wall Street Journal, 15 Jan 1980, 4; telephone interview with Roman Saliwanchik, 14 Dot 1978; "Supreme Court hears argument on patenting life forms," Science, 208 (4 Apr 1980), 31. The amicus briefs are with Diamond v. Chakrabarty, docket no. 79-136, 447 U.S.s 303.

43. In the Supreme Court of the United States, October Term, 1979, Parker v. Bergy et al, and Parker v. Chakrabarty, Brief on behalf of the People's Business Commission, amicus curiae, Dec 1979, 17-18; Diamond v. Bergy et al. and Diamond $v$, Chakrabarty (ref. 1), 10, 2021 . 
document-drew pointed attention, not only from MaLossi but also from several of the amici who filed on Chakrabarty's side,

What most exercised the other amici was the PBC's claim that patenting life was not in the public interest-a claim that the $\mathrm{PBC}$ sought to support by alleging that the Plant Patent Act of 1930 and the Plant Variety Protection Act of 1970 were directly responsible for a dangerous trend in the world's agriculture. The trend was the steady reduction in the number of varieties cultivated in major food crops-for example, the number of different strains of wheat-and the resultant narrowing of each crop's genetic diversity. Many native strains of plants were being lost as farmers replaced them with a few superior varieties. And the less genetically diverse a crop, the more susceptible it was to one or another disease. In 1970, a blight had wiped out nearly fifteen percent of the corn in the United States, which prompted a study by the National Academy of Sciences to note that "genetic uniformity is the basis of vulnerability to epidemics" and to add that "most crops are impressively uniform genetically and impressively vuinerable." 44

According to the $\mathrm{PBC}$, the reduction in crop varieties was the consequence of plant patents (the brief casually lumped together under the term "patents" both the genuine patents established by the 1930 act and the weaker protection certificates provided by the 1970 act). In the brief's analysis, seed and grain companies bred only those plants that could be patented-a small number, it held-and then (somehow) persuaded farmers to buy and substitute them for native strains. Furthermore, a few large corporations--frequently the same drug and chemical companies that were beginning to invest in biotechnology-had been acquiring independent seed companies and their plant "patents" (protection certificates). For example, Upjohn, together with three other companies, held $79 \%$ of such "patents" in beans. The overall result: "thanks to the patent laws, the bulk of the world's food supply is now owned and developed by a handful of corporations which alone, without any public input, determine which strains are used and how." 45

The PBC also caught the attention of other amici by insisting that allowance of the patenting of microorganisms as new compositions of matter would leave no scientific or legal basis to preclude the patenting of higher life forms, including mammals and the human manufactures of some

44. People's Business Commission (ref. 43), S-9; National Research Council, Committee on Genetic Vulnerability of Major Craps, Genetic vulnerability of major crops (Washington, D.C.: National Academy of Sciences, 1972), 1. See also U.S. Department of Agriculture, National Plant Genetics Resaurces Board, Plant genefic resources: Conservation and use (Washington, D.C., 1979).

45. People's Business Commission (ref. 43), 7-9, 12-13. 
Brave New World. Its brief predicted that patenting animals would lead to consequences identical to those it alleged had occurred with plants-a reduction in the world's domestic animal varieties and genotypes. Yet what most distressed the PBC-what it saw as "the essence of the matter" in the Chakrabarty case-was that to permit patents on life was to imply that "life has no "vital" or sacred property," that it was only "an arrangement of chemicals, or mere 'compositions of matter." "46

Solicitor General Wade H. McCree, Jr.'s brief did not endorse the PBC's on the merits but rather drew upon the Commission's claims to bolster its own principal legal argument-that Iegislation was necessary to extend patent protection to living organisms. Genetic engineering had raised issues of ethics (the creation of new life forms, including human ones); also of safety (recombinant organisms polluting the environment), continuing controversy over which, in the Solicitor's misinformed view, had led to a revision of the guidelines goveming recombinant research. Both issues had stimulated high disputes of a type that should be resolved by the Congress, not the courts. MaLossi reiterated his opinion why no Congressional action was required for a patent on Chakrabarty's bugs, stressing that the bugs had nothing to do with the kind of recombinant DNA that was controversial. However, he did feel compelled to point out to the Court the "distortion of the record" concerning recombinant. DNA presented in the Solicitor's brief, particularly with respect to public health and safety. Contrary to the Solicitor's impression, the revisions in the NIH guidelines indicated a progressive reduction, not enlargement, in the estimate of environmental risk in recombinant research. Beyond that, MaLossi deemed it best to let the prorecombinant amici represent their own interests to the Court. ${ }^{47}$

The amici obliged, especially the two-Genentech and the Pharmaceutical Manufacturers Association-with the greatest immediate economic interest in the outcome of the case. To both, the positions of the government and the PBC seemed to flout fact and logic. Their briefs sought to set matters straight and to provide what amounted to basic instruction in the fundamentals of the patent system as they saw it. Patents did not foster but actually penetrated industrial secrecy by compelling publication of the means and methods that led to a patentable product. Denying patents on life would throw corporate recombinant research deeper into the realm of trade secrets and hide from public scrutiny the degree to which the corporate

46. People's Business Commission (ref, 43), 11-12, 21-22, 27, 29-30.

47. Brief for the petitioner (ref. 43), 9-10, 17-21; Parker v. Bergy et al. and Parker $v$. Chakrabarty, Chakrabarty's brief in opposition to petition for wril of certiorari to the United States Court of Customs and Patent Appeals, Sep 1979, 6, n, 3; Diamond y. Chakrabarty, Brief for the respondent (ref, 43), 27-28. 
world was actually abiding by the NIH guidelines. Patents encouraged technological innovation, and they should be allowed to encourage it in genetic engineering, since the field was recognized as a richly promising contributor to the nation's high-technology competitiveness. By offering the incentive of certificate protection, the Plant Variety Protection Act had not reduced but had increased the number of plant varieties available to the American public. For example, as many new varieties of wheat had been developed in the seven years after the passage of the acts in 1970 as in the seventeen years before it. Genentech found it difficult to credit the argument that patents for life forms would diminish genetic diversity, "when any shove! full of backyard sod can yield micro-organic life in endless variety, and when genetic engineering itself permits the creation of new varieties." 48

Speaking from its own experience, Genentech called the patent system at its best "a pro-competitive system." one that could facilitate "the interposition of small but fruitful companies" in industries traditionally dominated by major firms. According to the Pharmaceutical Manufacturers, since 1970, as a result of the Plant Variety Protection Act, the number of seed companies had increased, especially in wheat, cereal grains, and soybeans (from six to twenty-five for soybeans). Also since 1970, almost 1,000 applications had been submitted for plant variety protection certificates on 57 distinct crops. About ten percent of these had come from agricultural experiment stations at colleges and universities; about twenty percent, from the six largest U.S. seed companies; and almost $70 \%$, from private breeders of all sizes. ${ }^{49}$

The American Patent Lawyers Association took the trouble to point out what should have been obvious to anyone--that living entities (innumerable varieties of domesticated plants and animais) had been treated as property since the advent of acquisitive man. Several of the amici conceded that allowing a patent property right in Chakrabarty's bugs might raise the question of the patentability of higher life forms. However, higher life forms were not at issue in the case, only microorganisms. The courts could only resolve the scope of the patentability of life if and when that question came concretely before them, not prospectively. The Pharmaceutical Manufacturers opined that, should the matter arise, it would be easy to draw a line between higher life forms and "the mindless soulless microorganism involved in Chakrabarty;" Genentech scoffed at the idea that a grant of Chakrabarty's claim would permit patents on human beings. ${ }^{50}$

48. Diamond $v$. Chakrabarty, Brief on behalf of the Pharmaceutical Manufacturers Association, amicus curiae, Jan $1980,13,26-28,48$; Brief on behalf of Genentech, Inc., amicus curiae, Jan $1980,13,17-18$.

49. Pharmaceutical Manufacturers Association (ibid.), 28-29; Genentech (ibid.), 3.

50. Diamond $v$. Chakrabarty, Brief on behalf of the American Patent Law Assosiation, Inc, 
Genentech supplied a trenchant counter to what the Pharmaceutical Manufacturers termed the "sky-is-falling" issues that had been insinuated into the case. The company's brief contended that it would defeat the patent system to permit avoidance of controversy to be a criterion of patentability, that the best science and invention were revolutionary, and often controversial, and that it was not the province of the Court "to attempt, like King Canute, to command the tide of technological development:"

The Patent System is, out of necessity, neutral. It cannot be too finely funed to the kind (as distinguished from the quality) of creation involved.....Most particularly must it abjure prior restraints, because they chill expression in literature and science alike. The neutrality of the Patent and Trademark Office requires that it leave to other agencies the regulation of technology, after the fact of its creation.

The pro-Chakrabarty amici briefs may have told on the government. Presenting its case in oral argument, Deputy Solicitor General Lawrence G. Wallace allowed to the Court that the case did not involve broad issues of public policy. It concerned only the narrow field of statutory interpretation and Congressional intent, to which he proceeded to confine his remarks. Chakrabarty was represented by Edward F. McKie, Jr., of Washington, D.C., who maintained that existing statutes were broad enough to allow his client's claim, that a living microorganism did not open a new area of patent protection. MaLossi remembered with pleasure that several of the justices wanted to know whether the bugs were the product of a new technology and that Wallace had to concede that they were not. Justice John Paul Stevens asked Wallace to explain why patents should be granted to new chemicals but not to newly fashioned bacteria. Wallace replied, lamely, that bacteria just did not "fit well within the statute," whereupon Justice William Rehnquist retorted, "Do you fear an invasion of the spores?" 52

On June 16, 1980, the United States Supreme Court held, by a vote of five to four, that Chakrabarty had a right, within existing statutes, to a patent on his microorganism. Chief Justice Warren Burger delivered the majority opinion, which echoed much of the reasoning in the opinion of Judge Giles Rich of the appeals court. Justice Burger enthused over the broad language that Jefferson had written into the patent law of 1793 , calling it expressive of its author"s "philosophy that "ingenuity should receive

amicus curiae, Jan 1980, 22; Phamaceutical Manufacturers Association (ref, 48), 20, 22-23; Genentech (ref. 48), 12.

51. Diamond $v$. Chakrabarty, Pharmaceutical Manufacturers Association (ref. 48), 15-16; Gententech (ref. 48), 4-12.

52. Arguments before the Court: Patents," The United States law week, 48 (25 Mar 1980), 3609-3610; telephone conversation with Leo MaLossi, 23 Aug 1988. 
a liberal encouragement" " and noted that all succeeding Congresses had left Jefferson's language virtually intact. Rejecting the contentions of the Patent Office, he found that the patent code as written was ample enough to accommodate inventions in areas unforeseen by Congress, including genetic technology, and to cover living microorganisms. In passing the plant acts of 1930 and 1970, Congress had "recognized that the relevant distinction was not between living and inanimate things, but between products of nature, whether living or not, and human-made inventions." Chakrabarty's bugs were new compositions of matter, the product of his ingenuity, not of nature's. As such, they were patentable under existing law. The minority's opirion, delivered by Justice William Brennan, argued precisely the opposite-that, in view of the legislative history of the two plant acts, the extension of patent protection to living microorganisms required new law. ${ }^{53}$

There was no particular ideological split between the majority (in addition to Burger, Justices Rehnquist, Stevens, Potter Stewart, and Наrry Blackmun) and the minority (besides Brennan, Justices Byron White, Thurgood Marshall, and Lewis Powell). Both the majority and the minority agreed that the question before the Court was the narrow one of statutory interpretation. However, Justice Lewis F. Powell, Jr. dissented in the case, as he wrote to Brennan, because of "the relative novelty of patenting a living organism, and by my conviction that the issue should be decided by Congress," At Powell's urging, Brennan's opinion included the observation-Powell wrote the passage-that the case concerned a composition that "uniquely implicates matters of public concern" and advanced that fact as a special reason for Congressional jurisdiction. ${ }^{54}$

Chief Justice Burger also took the trouble to address the apprehensions of the Patent Office and the People's Business Commission concerning the "grave risks" in genetic engineering. He observed that their briefs "present a gruesome parade of horribles" and reminded the Court "that, at times, human ingenuity seems unable to control fully the forces it creates." Burger further observed that genetic research with its attendant risks would likely proceed with or without patent protection for its products and that neither legislative nor judicial fiat as to patentability would "deter the scientific mind from probing into the unknown any more than Canute could command the tides." More important, the Court was "without competence" either to brush aside the horribles "as fantasies generated by fear of the unknown, or to act on them." Matters of high policy, embodying competing interests and values, were best handled by Congress and the

53. Diamond $\psi$. Chakrabarty, 447 U.S. 303, 100 S. Ct. 2204 (1980) at 2206-2212.

54. Ibid.; Lewis F. Powell to Mr. Justice Brennan, 29 May 1980, William J. Brennan MSS, Library of Congress, Container 535 . 
Executive-the political rather than the judicial branches of the government. The Court's task was the "narrow one of determining what Congress meant by the words it used in the statute" -which the Court had done-and once that was accomplished, its powers were "exhausted." 55

The New York Times advised editorially, "Relax. In sanctioning a patent for new forms of life created in the laboratory, the Supreme Court gave no license to create a race of supermen or a strain of bacteria to spread epidemic in the world. It settled a narrow point of patent law." Several legal authorities noted that, according to the statutes, a patent application had to include a description of the invention sufficiently detailed to permit a skilled worker to reproduce it-a requirement that the lawyers imagined would be virtually impossible to meet for a higher organism. ${ }^{56}$ However, dissidents opposed to experiments with recombinant DNA found no reason to relax. In a press release, the People's Business Commission announced that Brave New World was "now here" and was primed for corporate control. Along with others, Rifkin insisted that, despite the caveats of the lawyers and the courts, the Chakrabarty decision appeared to leave no legal obstacle to the patenting of higher forms of life-or, by implication, to the genetic engineering of such life forms. ${ }^{57}$

The dissidents were right on the legal point. In 1985, mindful of the Chakrabarty ruling, the Patent Office Appeals Board awarded a patent on a type of corn genetically engineered to contain a certain quantity of free tryptophan. In 1987, the Board cast another vote for legal logic, holding in ex Parte Allen that patents could in principle be granted on non-human animals. $^{58}$ And in April 1988, a U.S. patent was awarded to Harvard University on any non-human mammal genetically engineered to incorporate in its genome an oncogene tied to a specific promoter, scientists at the university having reduced the claim to practice in the form of an oncomouse. Diamond v. Chakrabarty was thus a landmark decision, with far-reaching implications for American patent law and for biotechnology.

Yet it was also significant for enlarging disputes over patents beyond legal technicalities and beyond even political economy. Immediately following the Court's decision, the general secretaries of the National Council of

55. Diamond v. Chakrabarty (ref. 53), 2211-12

56. The New York Times, 18 June 1980, A30; "Patenting life: Split perspectives," Science news, 118 (2 Aug 1980), 71 .

57. "Test-Tube life," Time, 115 (30 June 1980), 52-53; Peter Gwynne, "Court decision spurs genetic research," Industrial research and development, 22 (Aug 1980), 46; "The right to patent life," Newsweek, 95 (30 June 1980), 74; Los Angeles Times (17 June 1980), 11 ; C. Larry O'Rourke, "The Chakrabarty decision," Environment, 22 (Jul/Aug 1980), 5.

58. Ex Parte Hibberd, et al. (1985) 227 United States patent quarterly, 443; Ex Parte Allen, United States patent quarterly (1987), 1425. 


\section{Page 134 left blank intentionally}

Page 134 contains a cartoon from the Washington Post by Herblock printed on June 18, 1980. 
Churches, the Synagogue Council of America, and the United States Catholic Conference joined in sending a letter to President Jimmy Carter urging a reexamination of the patent laws and a government inquiry into the moral, ethical, and religious questions raised by genetic engineering. A Herblock cartoon, in the Washington Post, showed a clerk standing at the door to the U.S. Patent Office, telling a Dr. Frankenstein, who had his monster in tow, "I'm sorry-that's not exactly what the Supreme Court ruled on." 59 However narrow the Court's decision, it seemed in many quarters to. link the making of money to the making of monsters or, at least, to manipulation of the essence of life. As such, in the arena of biotechnology, it invited moral argument into the dynamics of patent deliberations for the first time in the history of American patent law and with consequences that remain to be seen. ${ }^{60}$

59. Herblock cartoon, Washington Post, 18 Jun 1980, A22; "Letter from three general secretaries," 20 Jun 1980, reprinted in President's Commission for the Study of Ethical ProbIcms in Medicine and Biomedical and Behavioral Research, Splicing life: A report on the social and ethical issues in genetic engineering with human beings (Washington, D.C., 1982), Appendix B.

60. Moral considerations have long been admissible in principle in European patent law. Article 53(a) of the European Patent Convention prohibits the issuance of patents for inventions that are contrary to public order or morality. The article has figured in the European Patent Office's handling of Harvard's application for a European patent on its oncomouse. 